\title{
A Textual Analysis of the Coverage of SARS and the Image of China --- A Comparative Analysis
}

\author{
Chia-ju Lin \\ Assistant Professor, International College, Ming-Chuan University \\ 250 , Sec. $5^{\text {th }}$, Chung-Shan N. Road, Taipei 111, Taiwan \\ Tel: 886-2-2882-4564 ext. $2692 \quad$ E-mail: L1977126@yahoo.com.tw
}

$\begin{array}{lc}\text { Received: August 24, } 2011 & \text { Accepted: October 2, } 2011 \quad \text { Published: March 1, } 2012 \\ \text { doi:10.5539/ass.v8n3p49 } & \text { URL: http://dx.doi.org/10.5539/ass.v8n3p49 }\end{array}$

\begin{abstract}
This paper examines the news coverage of the SARS (Severe Acute Respiratory Syndrome) crisis in 2003 in the US and UK newspapers via a qualitative approach, comparing the dominant news frames used across time and between the newspapers. The four newspapers frame SARS as a global health crisis which resulted from China's incompetence and mishandling. Moreover, China's deep-rooted political problems are illustrated because of the nationwide crisis, thus this health crisis is also perceived in the coverage as a serious political threat to the CCP ruling. The theme of China's initial concealment of information is selected and foregrounded in the newspapers, encouraging and reinforcing readers' negative perception of China as incompetent to handle a crisis. The image of the Chinese government in the SARS crisis is presented as an incompetent one which cannot effectively control the epidemic and attempts to hide the truth about the disease from its people as well as the outside world. In general, China represents not only an autocratic authority, but also an outdated communist country in the newspapers.
\end{abstract}

\section{Keywords: Textual analysis, News frames, SARS, China}

This paper is a case study analysing coverage of the People's Republic of China (PRC) in four major western newspapers regarding the outbreak of severe acute respiratory syndrome (hereafter SARS). Such an analysis is important for further understanding of how news frames produce particular meanings which construct representations of China. The study adopts a news textual analysis approach to dissect news reports in the New York Times (NYT), the Washington Post (WP), the Daily Telegraph (DT), and the Guardian (G). These have been selected because they are seen as 'quality' newspapers (Bell, 1991) and are therefore regarded as more suitable for research on international coverage since they carry a higher volume of foreign news than others. In addition, since American presses have received more attention to date, this paper broadens the scope of existing analyses by providing a comparative analysis which may generate a richer discussion of news frames on China. Meanwhile, the two British newspapers represent different political and ideological perspectives within British society. DT is traditionally quite conservative press while $G$ has a tradition of support for liberal causes. Their differing 'public idioms' (Hall, 1978) may suggest dissimilar representation of China; however, the similarity of their representations may indicate the extent to which there is a dominant frame in China reporting.

The paper is organized into four major sections. In order to understand the significance of the SARS case and provide some elementary information, the first section provides the background to the crisis. The second section sketches an analytical framework for news frame analysis and sampling. The third section comprises the news textual analysis which follows the thematic structure of the story. Finally, the conclusion asks why the health crisis and China were represented in the way they were.

\section{Introduction}

Before the SARS crisis, China's international reputation was quite positive since relations with the US and other significant powers in world politics were improving. It had just been selected as the host for the 2008 Olympics and joined the World Trade Organization. But in the course of the crisis, with China being reported as the origin of the disease in western media, and certain diplomatic action being taken with respect to China and the Chinese people; the image of China was affected as well. These issues are the primary focus of this case study. 
SARS was believed to have originated in southern China at the end of 2002, with the virus spreading quickly to neighbouring places such as Hong Kong, Singapore, Taiwan and northern China. From April 2003, SARS became 'globalised' because of its easily contracted nature, causing serious casualties in several places including China, Hong Kong, Singapore, Taiwan and Canada (Toronto). The epidemic caused grave concern around the world, and the international media devoted much space to reporting the global health crisis, including criticisms of the Chinese government's actions. By analyzing news coverage through textual analysis, together with an appropriate analytical framework, we can assess what kind of frames the selected newspapers used to tell the story and how China was represented.

\section{Theoretical and analytical framework}

The purpose of textual analysis is to disclose how discourse works to construct meanings that represent people, objects and events in specific ways. Discourse here is regarded as a particular type or pattern of language use connected with China, involving discursive practices that are constitutive of knowledge about China. Foucault suggests that discourses comprise a limited range of possible statements promoting a limited range of meanings (van Dijk, 1988). Each discourse represents a way of talking about, and therefore understanding, the social world from a particular perspective.

Disclosing the way in which discourses operate in media requires a systematic textual analysis, an examination of the processes of production and interpretation of texts and an analysis of the social context in which these texts occur (Fairclough, 1989). In van Dijk's words, reproduction of news information can be studied as a function of both textual and contextual properties of the communication process (Hall, 1978). Intertextual analysis involves signifying the historical discourses and backgrounds that texts draw on and the effects of this intertextuality; it also indicates the information and resources that writer and readers draw upon in production and interpretation processes. In this study, the emphasis is on news textual analysis which is important because it enables one to reveal the hidden patterns of form and meaning which demonstrate convincingly the representation of China in the newspapers.

In order to further understand how media discourse represents social discourse, framing theory is introduced and applied to the field of media study. 'Frames' are the assumptions used to structure discourse. In Gitlin's words, frames can be understood as 'persistent patterns of cognition, interpretation, and presentation, of selection, emphasis, and exclusion, by which symbol-handlers routinely organize discourse' (Gitlin, 1980). In general, frames involve selection and reconstruction; they select and call attention to particular aspects of the reality which logically means that frames simultaneously direct attention away from or exclude other aspects.

With respect to frames in news coverage, the thematic news frame places public issues in some general or abstract context. More specifically, the selection of a news 'angle' or 'storyline' which transforms an occurrence into a news event and, in turn, into a news report, is a news frame. These frames become an implicit part of, or the macrostructure of, news discourse.

Some scholars argue that news frames and major topics can be revealed by analyzing headlines, leads, subjects and propositions of news discourse (Brookes, 1995). Such qualitative study of media texts is variously called 'textual analysis' or, more recently, 'discourse analysis' (Jensen, 2002). It represents a significant theoretical as well as methodological contribution to the study of media discourse (Fairclough, 1992). Theoretically, news reports constitute a particular type of discourse which has more complex, higher-level properties, and it assumes that a higher level news topic can be derived from a sequence of lower-level topics in news text (van Dijk, 1988). Practically, they reduce the complex, detailed meaning structure of a text into a simpler, more general and abstract meaning.

The time span of this study is from April to June 2003 when the deadly epidemic finally tailed off. Ten items will be selected by purposive sampling from each newspaper according to the relevance to the SARS crisis and significant themes. Forty news articles will be analysed to find the news frames on both SARS and China.

\section{A textual analysis on China in the newspapers}

The analysis of news theme or topics in this case study indicates what frames, scripts and situation models (van Dijk, 1988) are likely to be activated and associated with the main subject reported on in conjunction with China.

\subsection{Theme structure of the SARS news}

Among the news coverage about the SARS crisis from April to June 2003 in the four newspapers, there is one central theme with a sequence of related themes through the news story. The leading theme of this story is the health crisis initiated in southern China, which involves the origin, transmission and seriousness of the disease, and people's suspicion and fear of the vital illness. SARS has been first found in southern China and it spread 
quickly with millions travelling 'without any control' (G21/04b) to northern China and neighbouring areas. The gravity of SARS and the acute situation in China is disclosed in the reporting, and China itself is depicted as the source of the epidemic and a primitive country. In the newspapers, the fear of SARS resulted from not only the highly dangerous nature of the disease, but also the lack of trust in the Chinese government. It leads to the second theme which is the reporting of the measures and actions taken by the Chinese government against the disease.

The second theme in the news story is the measures and actions taken by the Chinese government against the disease, such as massive quarantine, closure of public entertainment places and threat of execution for anyone who tried to spread the disease intentionally. The government also tripped two top officials of their power for their 'lack of vigour in containing the virus or for concealing cases' (NYT08/05). On this theme, the newspapers focused on two main points. The first was China's admission of mishandling and its concealing of information about SARS that was seen as at least partly responsible for the global outbreak; the second was China's tight information/news control during the crisis: 'the (SARS) subject was banned from all the Chinese media for almost a month' (G09/06), and 'media were told not to make cases of the disease public' (DT10/04).

The third related theme concerns the political effects of SARS. The coverage suggested that China's politics and economy have high priority for the four newspapers, and they framed the health crisis as a challenge for the communist authority. In the coverage, an unstable and struggling leadership of the Chinese Communist Party (hereafter CCP) was illustrated. In addition, China's political developments and future reforms also received much attention. In general, the newspapers were not too optimistic about China's move toward democracy after the SARS crisis.

The fourth theme comprises the criticism of the Chinese government in which China's political and social problems were highlighted and the negative image of China was projected. The first criticism was China's initial mishandling which was covered widely in the four newspapers. China was regarded as the one that should be responsible for the global spread of the vital epidemic since it dissembled about the extent of SARS. Its concealment of information resulted in great damage to China as well as to the whole world. In the coverage of SARS, China was a threat and troublemaker in terms of being an epicentre and a disseminator of a deadly disease.

\subsection{Reference to SARS in the newspapers}

For the four newspapers (see Table 1), the new disease of SARS was not only a health crisis to China, but also a crisis in terms of public confidence. In addition, there was also a severe threat to Chinese politics and economy which will be discussed in more detail below. The wording that the four newspapers used to refer to SARS, including crisis, hazard, shock, plague, test and threat, all suggested the seriousness and great impact of the epidemic. DT stated that SARS was a 'plague' (07/05) in our planet which denoted the severity and wide extent of this new epidemic, as well as fear of this unfamiliar disease. SARS news was treated as a 'crisis' (NYT19/05, DT21/04, 16/05, G21/04a, 16/05). The word 'crisis' denoted the gravity and influence of the issue; NYT also quoted one columnist's description as saying that SARS is like 'China's 9/11' (12/05) which of course represents a disastrous event to the US. NYT described it as 'the Chinese Communist Party's Chernobyl' (25/04). The mention of Chernobyl, another serious crisis in a communist country, is a metaphor which constructs an event or an experience in terms of another and makes the readers associate particular common features: SARS and Chernobyl both took place in communist countries and they both caused great damage and panic among societies. Most important, NYT believed that the two governments both intended to hide information about the crises, which has caused great damage to the whole world and has undermined public faith to a near-fatal degree. It suggested that communist authorities have the problems of credibility and accountability, and they are not trustworthy.

The adjectives that the four newspapers used to portray the disease also have the functions of indicating an objective property or expressing the producer's subjective evaluation and attitude to the event. The wording, such as 'nationwide' and 'national', were used to describe the extensive spread of the SARS crisis while 'serious, huge and deadly' were used to portray the degree of seriousness. Other adjectives including sudden, new and unknown were adopted as well to depict SARS which implied that this disease emerged unexpectedly and without any cautions and detailed information. The word 'unknown' disclosed the western world's uncertainty and fear of the 'plague' which they can not fully control.

\subsection{Reference to China in the newspapers}

China's image can be first inquired from the reference to it in the manifest news content. The reference of the 'epicentre or origination of the disease' (NYT08/05, DT29/04, and G21/04b, see Table 2) was the one that was 
mentioned in the four newspapers. In the coverage, all the newspapers suggested, though with different descriptions that the unknown disease was first found in China, which made China the place where the epidemic began. Besides, China was also the hardest hit and the place where the disease has been concentrated (DT29/04) because the cases of deaths and infections are nearly half of the cases reported in the world till the end of April 2003 (WP17/04). The relevance of 'the epicentre' indicated China's central position in this crisis, which implied that the representation of China in this case was a dark and enlightenment origination of a new, deadly virus, giving the audience a negative image.

In political terms, the words 'authoritarian' and 'dictatorship' were both adopted. These descriptions were strengthened and illustrated by the news reporting which framed the Chinese government as a dictatorship. The political dimension of China received much attention in the four newspapers, thus we will examine it in more detail later.

\subsection{Frames on the SARS crisis in the newspapers}

SARS was firstly framed as a serious health crisis originating from China. NYT suggested that the SARS virus had already 'infiltrated the city and the country' and it used a strong word 'devastating' (25/04) to portray the degree of the crisis. The international organization-WHO, was also cited in coverage as saying that 'this disease appears to be very strong in maintaining its virulence' (08/06). Such description of the characteristics of the disease as easily-infected and hard to eradicate has made the audience aware of highly dangerous nature of the disease, and encourages fear and a crisis in public confidence.

For the four newspapers, SARS was not only a medical problem; moreover, it has been framed as a severe challenge for the communist authority and a crisis in public confidence. In the reference to SARS, the health crisis was linked closely with China's politics. They argued that SARS was a 'huge shock for the entire party' (NYT12/05), a 'test for China's leadership' (WP22/04), and a 'political crisis' (DT 21/04). The coverage disclosed the weakness and complex of the Chinese government. NYT asserted that the Chinese leadership may be the next 'patient' (25/04) in the SARS crisis since China's politics and the new leadership was still 'unstable' $(25 / 04)$, and their political position may be challenged easily. A great quantity of coverage have attributed to China's politics, which indicated that China's political issues had high priority for the four newspapers.

SARS was also framed as a crisis in public confidence in the coverage. NYT quoted a Chinese as saying: 'no one had confidence in the government...the initial underreporting is exactly what I would have expected' (21/04). The first reason that the newspapers attributed to the confidence crisis was China's initial mishandling: news and information about disasters have been treated as a state secret. Because of the lack of information, 'rumours about the extent of SARS swirl around Beijing' (G21/04b). From the description, the readers may find that Chinese people and the government do not trust each other. The state was unreliable in matters of health, and feared that open information will cause panic and threaten social stability. Second, the crisis in public confidence may not take place only during the SARS threat. China's lack of credibility has lasted for a long time, and the Chinese people were being presented with two versions of reality, thus the government's initial concealment was predictable and 'normal' - and therefore effectively systemic.

\subsection{Frames on China in the newspapers}

A dishonest government which cannot be trusted. On the theme of China's actions toward SARS, the four newspapers foregrounded its initial hiding of information about the disease. In the coverage, the China government attempted to hide the extent of the disease since November 2002. On 21 April, they reported that the Chinese government officially admitted underreporting its SARS cases, and it was also accused of hiding information about the global spread of the disease.

The four newspapers adopted straightforward wording to describe China's behaviour, such as 'cover-up', 'conceal', 'hide', 'suppress' (NYT21/04, 12/05, WP 22/04, 10/05, DT10/04, 21/04a, 16/05, G21/04b). Further, WP and DT used sharper and negative words like 'deliberate deception', 'lying' (WP22/04, 01/05, DT21/04a) to strengthen China's intentional dishonesty. G reported that the information about the new epidemic was 'not disclosed in a timely manner' $(21 / 04 b)$. Compared to other newspapers, the wording used in G is more descriptive and less sharp; it used 'did not disclose in a timely manner' instead of stating 'lying' or 'deliberately deception' directly.

China's credibility was challenged before its official admission of hiding information. In order to prove China's reliability, the WHO was cited as evidence. WP quoted the WHO as source as saying: '... (the international community) does not trust China's figures' (17/04) and implied that China's gross underreporting has made it impossible to control and monitor the spread of the disease. G cited the WHO's statement proving the 
seriousness of the situation in China and indicated that China was concealing the truth about SARS. The words that $\mathrm{G}$ quoted from the WHO were the most straightforward and positive among the four newspapers. The WHO said that 'there is no question about that...there have been cases of SARS that have not been reported' (G17/04); and the WHO has been increasingly 'angry' (21/04a) about China's covering-up. The affirmative and sharp tone of the expression appeared in G strengthens China's covering-up of the extent of the disease.

G used contrary statements to reinforce China's inconsistency. It reported that before China's official admission of hiding information, China denounced the foreign media for 'irresponsible reporting' (21/04b) and claimed 'confidently' that everything was 'under control'. However, G reported later that China admitted its mishandling on SARS and sacked two officials since 'they were not being well-prepared for public health emergencies' (21/04a). Similar to NYT, G argued that China's attempt to portray its mishandling just an administrative incompetence, was an evasion of responsibility. Meanwhile, the reporting of China's earlier statement made a distinct contrast to its later admission of mishandling; the words that China used to defend itself emerged in the coverage, such as 'denounced', 'claimed', 'confidently' now reinforced the contradiction. Such information in the news text which contradicts the previous evasions discredited the Chinese government, makes its previous hiding seem more sarcastic and embarrassed, and allows the readers appreciate China's inconsistency and dishonesty.

After China's unprecedented actions of firing officials publicly and acknowledgment of mistakes, the newspapers still held a critical and skeptical perspective on it. In the coverage, WP stated that 'state-run newspapers carried a small item quoting Beijing's Communist Party secretary's apology' (22/04). WP foregrounded that the Chinese media devotes only 'a small (news) item' to report the official apology which was regarded as disgraceful by the Chinese authority; such practice made WP satirize that China's apology lacked sincerity and it intentionally played the crisis down.

In NYT, the WHO played a neutral and just role of offering 'truth' with credibility versus the incredible Chinese government. Hence NYT framed and strengthened its distrust of China through strategically quoting the WHO's statement as a collateral evidence. The statements from an international organization like the WHO gave a blunt and contradictory declaration (in G) or a negative evaluation of the Chinese leader's statements (in NYT); both ways of representation discredited the Chinese government and sharpened the negative image of China, making it the villain and the troublemaker.

In the coverage, the Chinese government was not trustworthy even to its own people. Chinese government 'did hide vital information from its own people and from the whole world' and 'did not keep people informed' (DT10/04). DT emphasized China's lack of credibility and responsibility and implied that ordinary people were being presented with two versions of reality. $G$ cited a Chinese as saying that '(the politicians) are playing politics with our lives' (09/06). For the government, the SARS crisis was a threat to the rule of the Communist Party, not to the people. In other words, it was suggested that the protection of the Party itself, and its grip on power, took precedence over people's lives thereby portraying outdated, autocratic governance and reinforcing a negative image of the Communist authority.

An ossified and unstable government. The Chinese government sacked two officials since 'they were not being well-prepared for public health emergencies'. In other words, the Chinese government was portrayed as treating SARS simply as an administrative problem. However, NYT held a sarcastic and sceptical position and argued that it was innocent for China to mistake the crisis as a result primarily of 'incompetence' and thought the problems will get solved by simply firing of officials. The coverage further indicated that China's political power does not necessarily go with responsibility. Because two fired Chinese officials ranked low in China's political hierarchy with limited power to make decisions in fact, thus the coverage argued that the fired officials were not the ones who really should be responsible for the SARS spread. The newspapers attributed the spread of SARS to China's problematic party politics. NYT addressed an argument that the Chinese government still handled a crisis via 'a Communist Party tradition' (25/04). WP argued that China's practice was 'textbook Chinese communism' (22/04) which means that the officials just ignored the problem and hoped it would go away. The word of 'textbook' in the coverage indicated China's traditional reaction, thus it was not surprising at its lying at all.

For the Chinese government, the rule of "social stability" (DT21/04a) was highly valued, and any crisis like SARS was regarded as a secrecy and may threat to the social stability. Therefore, China 'lied', 'covered', 'denied' and 'suppressed' in relation to the spread of SARS initially to protect this secrecy. Such statement in the coverage illustrated China's traditional thinking, and its secretive behaviour was regarded as a serious violation of the democratic principle of people's right to know. 
China's communist and conventional ways were also disclosed indirectly by reporting its action of public and frankly confession. The four newspapers all reported China's admission of cover-up of information about the disease and the firing of top officials, which was regarded as 'unprecedented'. For the western newspapers, a stereotype or an established scheme of values about China exists: China is a communist polity with ossified political and administrative system, and it is used to deal with events in a secretive way. Thus such coverage not only foregrounds China's 'extraordinary' action, but also discloses the western perspective and stereotype of China's politics.

In addition, China's politics was portrayed as unstable. The new leadership was headed by President Hu Jintao who took over as party leader at the end of 2002 and president in March 2003, but the former party chief Jiang Zemin still owned enormous influence 'behind the scenes' (NYT25/04). If the new leaders can not survive the SARS crisis, there will be another internally political struggle between current and former leaders. The coverage implied that the political position may be challenged easily and Chinese leaders were portrayed as power hungry. It also showed that the Chinese political system was not fully institutionalized and suggested that state actions were personally motivated or controlled.

An autocratic government. China's dictatorship was illustrated mainly through the reports on its rigid measures against the SARS crisis. Also, the newspapers linked previous events to remind and reinforce readers' perceptions of China. The first point in the newspapers concerned China's tight news/information control during the crisis. 'China's propaganda authorities banned all reporting about the disease' (WP31/05), and media were told 'not to make cases of the disease public' (DT10/04). The coverage of China's press ban and severe information control illustrated that the Chinese media was treated as a propaganda mechanism and was still controlled tightly even after China's apology.

For China, media was the part of the government, so the central authority had considerable power over it and unfavourable content such as SARS news will be suppressed. G reported that under the authority's instruction, the reporting about SARS must not 'damage social stability' (21/04b). NYT argued that China employed media to call on people to 'unify' against the disaster. In other words, the Chinese media were not only regarded as the part of the communist governance, but also served as a propaganda mechanism. The international media were severely controlled as well. G reported that CNN was censored and blocked (09/06) during the crisis. As a symbol of free media in the democratic world, CNN was taken as a western carrier of poisonous and hostile content by the Chinese government, especially when a crisis or a scandal took place, the international media will be vetted in case the Chinese people 'get infected' with its news.

In addition to the information/news control, China's aggressive stance and policy on public health against SARS also indicated its autocracy. In addition to severe policy of quarantines, the Chinese authorities also 'threatened' (DT 16/05, G16/05) to 'execute or imprison for life' anyone who tried to escape from SARS quarantine or to spread the disease intentionally. Such actions were taken as China's last choice to 'rescue its reputation' in the newspapers. For the Chinese government, harsh punishment was always simple and effective; but for western countries, it might not be civilized and appropriate, thus the newspapers used 'threaten' to describe China's stern measures. In other newspapers, China's dictatorship was also illustrated by the reporting of its news censorship and its 'irresponsible, secretive' way to handle the SARS crisis. Viewed in this light, the references that a newspaper adopted were in harmony with its reporting; and in this case, the coverage further reinforced China's image as repressive and autocratic in the readers' minds.

During the crisis, the Chinese people were suspicious and fearful of the epidemic, and a crisis in public confidence was approaching levels that followed the 'military massacre of unarmed demonstrators at Tiananmen Square' (21/04). NYT mentioned the student-led movement happened in Beijing which caused great panic and distrust of the government fourteen years ago, was equivalent to the SARS crisis. The events in Tiananmen Square was represented as a symbol of China's tyranny in western media; NYT used the word 'massacre' to define this event as a violent and brutal action, and described the protesters as 'unarmed' to show their innocence and peace. The mention of a previous event of the Tiananmen Square massacre is a technique of connection used by NYT that reinforces negative perceptions and attempts to convey that Chinese people lack confidence in their own government. WP used 'mass panic' (01/05) to portray the effects of the SARS crisis on China. WP and NYT both used 'panic' to describe people's fear about SARS, but the word of 'mass' in WP strengthened the extent of the anxiety.

China's autocracy was also conveyed through its distinct political system from western democracy. In addition to the news control, in fact, China's economic issues were closely related to its politics as well in the coverage. NYT suggested that a stable and growing economy was vital to the CCP's ruling because the CCP authority 
claimed that its rule was the "best way to offer great prosperity to 1.3 billion Chinese" (28/04); thus once it fails, its political legitimacy will meet a severe challenge. From the coverage it was clear that China's economy worked under tight political control, and the system was distinct from a free market one which was a characteristic of the western democracy.

A developing country which needs outside help. China's health care system was an explicit illustration of its underdevelopment in the newspapers. NYT suggested that because China's health care and social system remained primitive and undeveloped, and if the epidemic broke out in these areas, China may be in deep trouble. In the coverage, people's basic health service was not satisfied: 'not all suspected SARS patients can be hospitalized in a timely manner' (WP01/05) because of a lack of hospital beds and trained health professionals. The health and administrative system was also weak and inefficient.

In the coverage, China's health care system had two problems. The first was the insufficient investment. The WHO was quoted as saying that 'a surveillance network in China is not working' and 'the (Chinese) government has not invested in health in the last 30 years' (WP17/04). NYT described that China is the world's fastest-growing major economy. However, in contrast to the insufficient health resources, the communist authority was portrayed as only pursuing economic developments and growth, but did not offer even elementary social welfare to its citizens. Economic reforms and modernization have been carried out for two decades, but public health has declined. Even in the capital of this country, the problem of social resources insufficiency still remains.

Second, China's system was disorganized, outdated and inefficient and so it can not react in a timely and appropriate manner when a crisis broke out. A modern nationwide health system has never been established, and trained professionals were in deficit. Again, the newspapers evaluated China's situation according to western criteria and a contrast between 'advanced' and 'backward' was implied. In other words, China was on a lower level of progress than its western counterparts.

The reports on the health system illustrated the backwardness and underdevelopment of China. Further, NYT brought up the issue of AIDS in coverage as a comparison to denote that China encountered a similarly sad situation equivalent to Africa. It connected China with SARS and Africa with AIDS in its editorial (01/05) to express, on the one hand, the seriousness of SARS; on the other hand, it noted that China was part of the Third World where a deadly disease has broken out and the authorities were incompetent to deal with the problem. The concept of "Third World" evoked notions of inferiority and development where China was on a lower level of progress than its western counterparts.

China was categorized as a 'developing country' or part of the Third World in the coverage. NYT argued that China's economic system centred on manufacturing, unlike the US, a 'developed' one with a large service sector. This placed the US in an advanced and guiding role. NYT's editorials $(01 / 05,19 / 05)$ argued that China required a better disease surveillance system as well as more ambitious political reforms and modernization to catch up China's globalised and market-driven economy. The others also adopted western political, social and economic standards and principles to criticise and offer advice to China. Here, G argued the western world has to take responsibility for health in other countries. In this argument, China and other underdeveloped and developing countries were regarded as a group contrary to the West. This argument was based on assumptions about who is likely to possess the material capability to provide aid and who is likely to be a recipient. In the coverage, China was on a lower level of progress and was helpless and backward, and the western countries represented an advanced force as well as providers and rescuers who offer assistance and service.

China's political reforms. The coverage about China's mishandling and its ossified system lead to the reporting about the needs of political reforms. China's new leadership once declared that they wanted to modernize media and government; the four newspapers devoted fairly space to China's political reforms although the reporting was not positive.

For WP, China's actions against SARS may only be a strategy to consolidate the current leaders' power. In order to justify this argument, WP quoted a US expert as saying that 'the current political system in China is not designed to allow press freedom, no matter how nice and benign Hu or Wen may be' $(02 / 05)$ which suggested that China's problems were systematic and institutional and could not be addressed by simply replacing leaders. DT argued that China's announcement of reforms seemed to have 'failed' after the SARS crisis. China's media still had no rights to cover important domestic issues and had to serve the ultimate goal of social stability. In addition, China's political modernization did not challenge the rule of the Communist Party. Thus, China still had a 'monolithic dictatorship' (21/04a) and its alleged modernization was totally meaningless and useless according to DT. This argument showed that the authorities refused to yield grounds while maintaining intact 
most of its controls; in other words, it was essentially negative about China's reforms which still had long way to go to achieve "democracy".

\section{The image of China and the Chinese people in the SARS news}

The newspapers argued that China was seen as at least partly responsible for the global spread because of its initial mishandling. WP pointed out sarcastically that the serious outbreak had to 'thank to' China's outdated system of governance. G criticised China's traditional response of concealing and suppressing to bad news had seriously worsened its credibility. DT stated that the SARS crisis was an 'international embarrassment' for China. In sum, SARS has earned China a 'humiliating public rebuke' (G22/05) and the reputation and credibility of the government have also been damaged. Therefore, after Beijing's 'belated honesty' (G21/04a), the newspapers and the WHO still held questionable attitudes toward China's information about SARS; for instance, G argued firmly that China still underreported and underestimated the extent of SARS. Here, China was described as an irresponsible country and a troublemaker and the ruination which was negative to its image, and it was not accountable anymore.

China's national image, however, was only one casualty. The Chinese people have been besmirched as 'people who carried virus of SARS' (WP27/04), and '94 countries have instituted some type of quarantine or limits or all-out bans on them' (01/05). Apparently, the government's mishandling caused discrimination against its people abroad. NYT described them as 'international pariahs' (NYT12/08) when they go abroad. Such reference described the plight of Chinese during the SARS crisis, and also strengthened westerners' stereotype and prejudice against Chinese as constituting a 'Yellow Peril'. This involved some background knowledge on the part of the reader triggering common-sense beliefs operating in the reader's social context. Moreover, the Chinese people were presented as 'victims' under the communist authority. In the coverage, they were predominantly constructed as affected and passive participants. With the government's mishandling and concealing the information combined with insufficient resources, the Chinese citizens became helpless victims of SARS. They were frequently presented in news text in terms of numbers or casualties which was backgrounded by attenuation as the 'mass' instead of presenting them individually.

\section{The sources adopted in the newspapers}

The sources quoted in the four newspapers were also significant. They were used to endorse, evaluate or invalidate the statements or actions of the Chinese actors, which involved the news producer's assessment of the truthfulness of the statements or actions and consequently the reliability of the sources. In this case, the direct sources in news text were analysed and there was a wider variety of western sources which was drawn upon by the newspapers, such as western diplomats, observers, analysts, and experts; on the contrary, the Chinese sources were limited and monotonic.

The seriousness of SARS crisis around the world and in China was also presented via the information on the number of deaths and casualties which greatly appeared in the four newspapers. The statistics adopted from the WHO showed that China had nearly half of the cases reported in the world. Thus China became not only the source of the disease, but also the hardest hit in this crisis. Most of the statistics in the newspapers came from the WHO, which was regarded as an informed and reliable source, playing the role of instructor, evaluator and researcher. It issued warnings against travel to the affected areas and it did research on the evolution of, spread of and vaccine for SARS. Because of its credibility, quotations from it were awarded high priority and were often used strategically to provide collateral evidence, especially in the coverage about the extent of the disease and China's health system in this case study.

In NYT, the WHO played a neutral and just role of offering 'truth' with credibility versus the incredible Chinese government. In addition to the statistics from the WHO, the coverage illustrated the gravity of the epidemic by citing statements from anonymous sources (see Table 3), especially WP and DT. WP argued that in the early stage, the information about SARS was treated as state secrecy by the Chinese authority. Further, WP used anonymous sources from universities, hospitals and citizens as 'evidence' to prove that what happened in China was more serious than the government claims. For instance, 'a source said that a retired designer was infected with the virus after he went to hospital for treatment of a leg fracture. During his stay at the hospital, two of his roommates died. Several friends and family members who visited the man at the hospital also developed symptoms' (WP17/04), such description not only illustrated the seriousness and virulence of the disease, but also uncovered the incompetence of China's health system in controlling the epidemic. DT also cited anonymous sources from hospitals in Beijing to confirm that the actual situation in China was much worse than the government admitted. These sources included doctors, nurses and patients who had credibility because of their personal experience of SARS. In the coverage, these citizens 'accuse the Beijing government of lying about the 
spread of the killer virus' (10/04). Some doctors directly claimed that the government was talking 'nonsense' $(10 / 04)$. The representation of these Chinese citizens was brave and honest since they may encounter prosecution under state secret law. In this case, the Chinese people were taken as anonymous sources which positioned themselves in opposition to the government in challenging the official argument and providing evidence to invalidate the authorities. They were quoted in eyewitness accounts of the SARS crisis of which they were the victims, and they were presented as credible while the Chinese government is not.

The statements by the Chinese government or officials were quoted mostly to explain the SARS situation in China, but they sometimes contained illogical, unreasonable or tyrannical statements. For example, China's statements about the aggressive punishments for spreading SARS deliberately conjured up a negative image to the readers. And confident and firm statements about SARS control and statements of public admission of mishandling were both quoted in the coverage to discredit the Chinese authorities.

In the reports on China's politics, the sources that the newspapers used include the Chinese people, reporter, anonymous sources and a US expert. Brookes (1995) argues that non-western civilians are quoted as telling of atrocities and commenting on the actions, and these are usually presented as credible. In this case, the Chinese reporter and the ordinary people under the communist regime were cited to express their opinions on the Chinese government and its politics, and the quotations were both negative about China. In news text, western experts were usually taken as reliable and credible. The US expert here was cited to evaluate and comment on China's political system, and his statement was treated positively as conclusive. Further, western sources were portrayed as reliable and credible as well and at the same time were used to negatively evaluate China's statements or actions.

\section{Pairs of key concepts within the newspapers}

An analysis of the news text revealed several pairs of key concepts: democracy and dictatorship, help and helplessness, advanced and backward and the West and China. These contrasts are the technique used through the four newspapers which stereotyped and framed China.

First, the actions and measures against SARS that the Chinese government were negatively presented in the four newspapers, including its initial cover-up of information about SARS and its aggressive political, social and news control. The newspapers also covered China's communist political system and argued that its ossified and inefficient government needed comprehensive reforms. Therefore, China was not only represented as an autocratic authority, but also a communism which was outdated, repression and evil. By contrast, both the values foregrounded in the coverage and the principles used to judge China portrayed the democratic US and UK favourably, as much more advanced in social and political terms.

In the coverage, the mainstream ideology of democracy and freedom in western societies was running through the coverage. For instance, the Chinese government was portrayed as using media as a propaganda mechanism to disseminate official information favourable to itself, thus symbolising China's dictatorship. For western democracies, press freedom may be a fundamental principle and condition to a democratic system which forms a power of surveillance to governments. Media content may reflect certain naturalized assumptions or beliefs operating within the society in which a text is produced. Viewed in this light, China does not have a free press to monitor its government, thus it is regarded as an autocracy.

In addition, China's information/news control also reflected the regime's top priority of social stability. The stress of the social stability here highlighted the characteristic of a communism in contrast with democracy. The former favours collectivism which foregrounds social and national unity and stability, and believes that communist rule is in the best interests to its people. Thus, media, as a branch of the national organization, should be controlled by the central authority and serve as a propaganda mechanism. In contrast, a democracy values civil and political rights, including press freedom. Under this principle, media should be independent of government's control.

The ideology of democracy was also illustrated in the coverage about China's political reforms. In general, the four newspapers argued that it may be too optimistic to expect that China will move toward democracy after the SARS crisis. The news coverage about political reforms in western newspapers may suggest the beliefs that progress is the direct result of change involving the introduction of a universally applicable political system. Among the four newspapers, WP was the one which stated the principles of democracy most clearly and positively. It clearly supported the value of democracy as beneficial and advanced, and this constituted the basis or ideology that framed the coverage of China. A democracy should have a system of checks and balances, the independent watchdog agencies and free press, and the West can be seen as the model of democracy and has offered the right direction to achieve it. In the coverage, these principles or rules were used to examine China's 
current political system; for example, DT argued that China's reforms have 'failed' because it apparently did not meet the democratic rules. As a communist country, which was thought to be opposite to a democracy, China's political and social system was ossified and backward and there was no mechanism to ensure the accountability of officials. Therefore, China's reforms will not 'succeed' (from the west's point of view) unless it follows the western ways and reforms accordingly.

The second contrast concerns help and helplessness. China was portrayed as incompetent in handling its own affairs because of its ossified and inefficient system. Thus it needed outside help from international organizations and the West. The latter entity therefore took the roles of leader, mediator, provider, and bringer of resources. International organizations and the West were presented not as 'interfering' in China's internal affairs but as offering their 'help'. Meanwhile, the coverage reported that China expressed a willingness to cooperate with the WHO and accepted its inspection after the admission of initially hiding information. This further strengthened the legitimacy and morality of West's roles as helper.

Third, the coverage includes China's health care system and its measures to contain the disease, which illustrated the shortage of trained professionals and an inefficient health system. Compared to China, the West enjoyed a higher level of development as seen in the reporting of British medical facility and the research on SARS. Most of the professional institutions or university experts cited in the coverage are western. They were presented as reliable and credible with developed facilities, technology and resources.

Fourth, China was frequently presented as a country categorized in a distinct group from the West. In other words, there was a dichotomous vision of 'us' and 'them' in the coverage, where the word 'us' may be broadened to refer to 'the democratic nations' or 'the West'. In NYT, it used Chernobyl to illustrate the severity of SARS in China. The two communist countries were organized into one block with similar and negative political systems and policies toward crisis, and the US and the UK were grouped in the democratic block contrary to them. China was also regarded as part of the Third World, or the developing countries in the coverage. G argued that 'the western world' should take responsibility for health in 'other countries', which implied that 'other countries' cannot handle their own health problems and that advanced western countries should provide help. Fowler (1991) argues that the popular press sometimes cast 'them' in a bad light to place a fence around 'us'. In this case, negative representation of China (and the communist countries or the Third World behind China) also suggested a positive image of the West. In sum, the multiplicity of news themes around the three contrasts resulted in the foregrounding of China as autocratic, helpless and backward. These meanings were reinforced by the themes of democracy, help and advanced standards in the west. In summary, China was given a predominantly negative representation through the use of these classification schemes.

\section{Conclusion}

According to Hester (Hester, 1976), the cultural, economic and national interests of a country may influence the news determinants. For example, in the economic dimension, where economic relationships are strong, more information flow will be observed between nations. Compared with the UK, the US has a closer and stronger relationship with China in economy, military and regional terms, thus American newspapers may devote more space to analysis apart from coverage of SARS.

In this case, compared with two American newspapers, DT and G had fewer news articles about SARS in number, and devoted less space to analysing China's political and economic system and practice. For DT, it was not just China that is newsworthy. It paid attention to the situation in Britain, including the precautions of the government, the disputes among parliament and influences on Britain. DT and G paid more attention to the situation in Britain as well as in Europe apparently because of its geographic proximity and its possible effects on Britain. Compared to G, DT emphasized domestic debates more than G did; on the contrary, G covered the situation in Europe more than DT. Thus it can be seen that DT offered more information which was more closely related to British people. As stated at the beginning, two British newspapers, which were considered to hold opposing ideological positions, illustrated quite similar frames on SARS news as well as on China, which indicated that there may be a stereotypical and dominant discourse in reporting on China.

It is often claimed that journalist collects facts, reports them objectively, and the newspaper presents them fairly, in language which is designed to be unambiguous, undistorting and agreeable to readers (Fowler, 1991). In other words, professionalism assumes that journalists actually grasp the 'real world' and describe what happens in that world. However, news reports as a practice and a product of the social and political world constitute a particular type of media reality. It is not simply 'facts' but 'stories' (Bell, 1991) in terms of specific lexical sets, structure, direction, angle, viewpoint and frame. In other words, news stories place public issues in some general or abstract context through specific frames, selecting some aspects of a perceived event and making them more 
salient in a communicating text so as to promote a particular definition, interpretation, and evaluation.

In this case study, China's initial concealment of information was selected and foregrounded in the newspapers, encouraging and reinforcing readers' negative perception of China. Generally, the four presses used similar words to describe China's behaviour while WP and DT adopted the strongest word, 'lying', as an indictment of the credibility of the Chinese government and its anachronistic practices of concealment which were unsustainable in an era of global communication and advanced technology. China's lack of credibility was also illustrated and strengthened via the reports on the Chinese people's distrust in their government.

In the coverage, China's politics received much attention. It suggested that the newspapers selected it as a point with high priority, and other issues were simultaneously excluded, such as China's economic developments and its relationships with the US and the UK. China's political system was framed as largely responsible for an inadequate response to the SARS crisis. Top leaders within the Party remained in power after the crisis, and the economy, health system and news flow were still manipulated by an ossified system for political purposes. It showed up the contrast between the different systems of China and western countries in terms of political responsibility and social control. China's politics represented as closed and autocratic with few changes over the last forty years. DT covered the new leadership's wish for modernization reforms, but held a skeptical and negative view of this because traditionally, the most important principle under the communist authority has been that the rule of the party cannot be challenged. Further, China's initial handling of the SARS crisis still followed a conventional path showing no inclination for reforms.

News reports constitute a particular type of discourse which is socially constructed by news people in which they engage in 'strategic rituals' as they work with each other and sources to make news reports (Manning, 2001). Most importantly, according to framing theory, it is never possible to reproduce objective truths since constructed news is simply approximate to the reality in the 'real world'. Allan (Allan, 1995) therefore suggests that rather than gauging news media coverage against 'reality', we may turn our attention to the news texts themselves, exploring how news texts present themselves as 'truthful', rather than to test them against truth.

In the field of media studies, researchers are interested in how the media mask their ideological positions, embodied in their attitudes and opinions, in the way they present people and issues (Bell, 1991). Textual analysis dissects news discourse to find not only news frames, but also the hidden ideology within it. In this case study, the newspapers (especially the American ones) judged China according to the standards of western democracy; thus the Chinese government was described as lacking a system of checks and balances, independent watchdog agencies and a truly free press. China's social developments and political reforms were also examined according to western standards in the coverage. Such illustrations cast China in a negative light in contrast with democratic countries which were regarded as much more advanced and developed. In the four newspapers, China was uniformly framed as an autocratic country in opposition to the UK and the US. However, the American newspapers strengthened the value of democracy more than the others. Gramsci (1971) argues that the more naturalized a discourse becomes, the more it loses its visible ideological character and becomes embedded in beliefs, social identities and social relationships. The longer they are entrenched, the more acceptable they become. In this case study, the ideology of western democracy has become a universal frame of reference and common sense by which China was shaped and examined.

In sum, the representation of China was negative in the four newspapers. In the coverage, the Chinese government was condemned internationally because of its covering-up of information about SARS. China's coverage was as a developing country with an ossified communist system which needed aggressive reforms in many aspects. China was incompetent to handle the SARS crisis and needed outside, especially western, help. Moreover, the Chinese people were treated sceptically as pariahs abroad. After China's officially public confession, the four newspapers still held a doubtful attitude about China's information, and they argued that there is still a long way to go for China to achieve democracy.

\section{References}

Allan, S. (1995). News, truth and postmodernity: unraveling the will to facticity, in Adam, B. and Allan, S. (eds.), Theorizing Culture: An Interdisciplinary Critique after Postmodernism. London: UCL Press, p. 131.

Bell, A. (1991). The language of News Media. Cambridge, MA: Blackwell.

Brookes, H. (1995). Suit, tie and a touch of juju - the ideological construction of Africa: a critical discourse analysis of news on Africa in the British press. Discourse \& Society, Vol. 6. http://dx.doi.org/10.1177/0957926595006004002

Chung, Wei-Wen \& Tsang, Kuo-Jen. (1997). Extending the Concept of Framing: The Discursive Turn. Paper presented to the conference on "Framing in the New Media Landscape." Columbus, SC: The University of South 
Carolina.

Fairclough, N. (1989). Language and power. London: Longman.

-----. (1992). Discourse and Social Change. Cambridge: Polity Press.

(1995). Media Discourse. London: Edward Arnold.

Fowler, R. (1991). Language in the News. London: Routledge.

Gitlin, T. (1980). The whole world is watching: Mass media in the making and unmaking of the New Left. Berkeley: University of California Press.

Gramsci, A. (1971). Selections from the prison notebooks of Antonio Gramsci. London: Lawrence and Wishart.

Hall, S. (1978). The social production of news, in Hall et al., Policing the Crisis: Mugging, the State, and Law and Order. London: Macmillan, p. 61.

Hester, A. (1976). International Information Flow, in H. Fischer and J. Merrill (ed.), International and Intercultural Communication. New York: Hastings House Publishers.

Jensen, K. (ed.) (2002). A Handbook of Media and Communication Research. London: Routledge.

Manning, P. (2001). News and news sources: a critical introduction. London: Sage.

Martin, C. (2004). Framed!: labor and the corporate media. Cornell University.

Van Dijk, T. (1988a). News as Discourse. New Jersey: Lawrence Erlbaum Associates.

Van Dijk, T. (1988b). News Analysis: Case Studies of International and National News in the Press. New Jersey: Lawrence Erlbaum Associates.

\section{Notes}

Note 1. Reference refers to an expression of the producer's subjective evaluation and attitude to a particular event or entity.

Note 2. Sources statistics comes from the calculation of the frequency of quotation in the coverage. For example, WP reports that "Beijing University suspended classes... after an economics professor contracted the disease, sources at the school said" (17/04), in which "sources" is labelled as "source" under the Chinese category.

\section{News headlines}

NYT

The SARS epidemic: China admits underreporting its SARS cases-21/04

The SARS epidemic: possible next patient: the Chinese leadership - 25/04

The SARS epidemic: outbreak of disease brings big drop-off in China's economy-28/04

Quarantine ends for some in Beijing, but infection spreads—-08/05

Spread of SARS acts as a rude awakening for China-12/05

China issues strict rules on reporting of disease $-14 / 05$

The SARS epidemic: market for Chinese-American delicacy plummets-23/05

The SARS enigma- $08 / 06$

The cost of SARS - 01/05, editorial

Diagnosing SARS in China-19/05, editorial

WP

Underreporting, secrecy fuel SARS in Beijing, WHO says-17/04

Epidemic is a "test" for China's leadership-22/04

China's crisis has a political edge; leaders use SARS to challenge recalcitrant parts of government-27/04

SARS causes "mass panic" in Beijing, official says—01/05

China feels side effects from SARS-02/05

China turns to informers to fight SARS; reliance on Communist Party members reflects a common strategy during crises-20/05

China gets defensive on SARS record; change in tone dampens hopes for political reform-31/05

SARS exposed world's weak spots; experts welcome hotline for public health emergencies, new powers for WHO-15/06

Can China cure its severe acute reluctance to speak? - 27/04, outlook 
What it will take to transform China-19/05, editorial

DT

China lying over virus, say doctors in Beijing - 10/04

China forced to tell the truth about scale of outbreak. Crisis shows that despite political modernisation, officials must still toe the line-21/04a

Communist Party gets a nasty case of control-freak jitters-21/04b

"Feeble and complacent" SARS policy attacked as virus claims more victims-25/04

SARS "has peaked" despite more cases in China-29/04

"I've recovered from SARS—-but why did no one tell my colleagues?"-01/05

China's SARS quarantine cheats face execution-16/05

Hong Kong is back in business after SARS-31/05

Should we be scared of SARS? Scientists have identified the SARS virus and the symptoms can be treated-25/04, features

A plague on our planet $-07 / 05$, analysis

G

China "still hiding" many SARS cases—17/04

China says SARS outbreak is 10 times worse than admitted-21/04a

Chinese cover-up creates new sense of insecurity in face of SARS epidemic: leaders reveal 'grave' situation as public's faith is shattered-21/04b

Spread of SARS: anatomy of the deadly China syndrome: virus SARS is first of many epidemics to come-25/04a

China opens door to world help with its SARS crisis-30/04

SARS still out of control, warns WHO director-07/05

China threatens death to anyone spreading SARS deliberately-16/05

Media: seizing the hour: China's journalists are pushing for increased openness from a government reeling from the SARS crisis- $09 / 06$

The new killer threatening rich and poor alike: SARS is a global danger and should shake the west's complacency - 25/04, Comment \& Analysis

Fatally wounded: economic liberalisation destroyed-22/05, Comment \& Analysis

Table 1. Reference (Note 1) to SARS

\begin{tabular}{|c|c|l|}
\hline Newspaper & Date & \multicolumn{1}{|c|}{ Reference } \\
\hline & $21 / 04$ & a sudden new health hazard, a grave danger to society, a \\
crisis in public confidence \\
the Chinese Communist Party's Chernobyl \\
& $25 / 04$ & $\begin{array}{l}\text { China's 9/11, a huge shock for the entire party } \\
\text { NYT }\end{array}$ \\
& $12 / 05$ & a health crisis \\
\hline & $22 / 04$ & a test for China's leadership, an issue that threatens public \\
& & health, the economy and the nation's image around the \\
& & world \\
& $27 / 04$ & the threat to China's economic plans \\
the most serious political and economic threat \\
& $20 / 05$ & the first major test to the world's ability to fight a \\
& $15 / 06$ & dangerous new infectious disease in the new millennium \\
\hline & $21 / 04$ & a political crisis \\
& $07 / 05$ & a plague on our planet \\
& $16 / 05$ & a nationwide health crisis \\
\hline DT & $21 / 04 \mathrm{a}$ & a health crisis \\
& $21 / 04 \mathrm{~b}$ & a deadly disease \\
& $16 / 05$ & a national crisis \\
\hline
\end{tabular}


Table 2. Reference to China

\begin{tabular}{|c|c|l|}
\hline Newspaper & Date & \multicolumn{1}{|c|}{ Reference } \\
\hline NYT & $25 / 04$ & $\begin{array}{l}\text { patient } \\
\text { the world's fastest-growing major economy, the } \\
\text { authoritarian government } \\
\text { the new global epicentre of the epidemic }\end{array}$ \\
\hline WP & $08 / 05$ & the hardest hit \\
\hline DT & $21 / 04 \mathrm{a}$ & $\begin{array}{l}\text { monolithic dictatorship, a densely populated country } \\
\text { where the outbreak began }\end{array}$ \\
\hline G & $29 / 04$ & $21 / 04 \mathrm{~b}$ \\
& $30 / 04$ & $\begin{array}{l}\text { the epicentre of the virus } \\
\text { the world's most populous nation }\end{array}$ \\
\hline
\end{tabular}

Table 3. (Note 2) news sources in four newspapers

\begin{tabular}{|c|c|c|c|c|c|}
\hline & & NYT & WP & DT & $\mathrm{G}$ \\
\hline Chinese & $\begin{array}{c}\text { official/government } \\
\text { people } \\
\text { media } \\
\text { expert } \\
\text { source }\end{array}$ & $\begin{array}{c}16 \\
6 \\
6 \\
4 \\
0\end{array}$ & $\begin{array}{c}19 \\
2 \\
5 \\
2 \\
10\end{array}$ & $\begin{array}{l}2 \\
2 \\
3 \\
0 \\
4\end{array}$ & $\begin{array}{c}12 \\
1 \\
6 \\
1 \\
0\end{array}$ \\
\hline The US & $\begin{array}{c}\text { official/government } \\
\text { experts/scholars } \\
\text { people } \\
\text { media }\end{array}$ & $\begin{array}{l}2 \\
6 \\
4 \\
0\end{array}$ & $\begin{array}{l}2 \\
5 \\
0 \\
0\end{array}$ & $\begin{array}{l}0 \\
1 \\
0 \\
0\end{array}$ & $\begin{array}{l}0 \\
0 \\
0 \\
0\end{array}$ \\
\hline The UK & $\begin{array}{c}\text { official/government } \\
\text { expert } \\
\text { people }\end{array}$ & $\begin{array}{l}0 \\
0 \\
0\end{array}$ & $\begin{array}{l}0 \\
0 \\
0\end{array}$ & $\begin{array}{l}5 \\
6 \\
2\end{array}$ & $\begin{array}{l}4 \\
0 \\
1\end{array}$ \\
\hline Hong Kong & $\begin{array}{l}\text { expert } \\
\text { authority }\end{array}$ & $\begin{array}{l}2 \\
0\end{array}$ & $\begin{array}{l}0 \\
1\end{array}$ & $\begin{array}{l}0 \\
2\end{array}$ & $\begin{array}{l}1 \\
0\end{array}$ \\
\hline \multicolumn{2}{|c|}{ WHO } & 7 & 7 & 5 & 9 \\
\hline \multicolumn{2}{|c|}{ Other foreign government/officials } & 0 & 1 & 0 & 3 \\
\hline \multicolumn{2}{|c|}{ News agency } & 1 & 0 & 0 & 0 \\
\hline \multicolumn{2}{|c|}{ International organizations } & 5 & 0 & 0 & 1 \\
\hline \multicolumn{2}{|c|}{ Other } & 7 & 7 & 2 & 8 \\
\hline \multicolumn{2}{|r|}{ Total } & 66 & 61 & 28 & 47 \\
\hline
\end{tabular}

